\title{
KINERJA KEUANGAN PERUSAHAAN INDUSTRI BAJA NASIONAL SEBELUM DAN SESUDAH DITERBITKANNYA PERATURAN MENTERI PERDAGANGAN NO. 22 TAHUN 2018
}

\author{
Mochamad Riza Inayatullah, Bambang Mulyana \\ Universitas Mercu Buana (UMB) Jakarta, Indonesia \\ Email: riza_ina@yahoo.com; bambang_mulyana@mercubuana.ac.id
}

\begin{abstract}
Abstrak
Dalam meningkatkan laju pertumbuhan ekonomi dengan melalui pengembangan infrakstruk. Pemerintah merencanakan membangun proyek yang dianggap strategis dan yang paling urgent. Penelitian ini bertujuan untuk mengkaji kinerja keuangan sebelum dan sesudah diterbitkannya Peraturan Menteri Perdagangan No. 22 (Permendag) Tahun 2018 tentang Tata Niaga Impor Besi atau Baja dengan menggunakan rasio likuiditas, rasio solvabilitas, rasio profitabilitas, dan rasio aktivitas. Penelitian ini menggunakan data emiten sub sektor logam dan sejenisnya yaitu perusahaan yang bergerak dalam industri baja. Teknik pengambilan sampel yang digunakan adalah sampel jenuh. Terdapat 8 perusahaan yang memenuhi kriteria sebagai sampel. Metode analisa yang dipakai adalah statistik deskriptif dan One Way Anova (Analysis of Variance). Hasil penelitian menunjukkan bahwa CR, QR, CaR, DER, DAR, CCR, ICR, ROA, PTO, dan TATO mengalami perubahan signifikan sejak diterbitkannya peraturan. Sedangkan pada GPM, NPM, ROE, BEP, ITO, dan RTO tidak mengalami perubahan yang signifikan sejak diterbitkannya peraturan.
\end{abstract}

Kata Kunci: kinerja keuangan; rasio likuiditas; rasio solvabilitas; rasio profitabilitas; rasio aktivitas

\section{Abstract}

This study aims to examine financial performance before and after the issuance of the Minister of Trade Regulation (Permendag) No. 22 year 2018 concerning the Iron or Steel Import Trading System using the liquidity ratio, solvency ratio, profitability ratio, and activity ratio. This study uses data on issuers of the metal sub-sector and the like, namely companies engaged in the steel industry. The sampling technique used is a saturated sample. There are 8 companies that meet the criteria as a sample. The analytical method used is descriptive statistics and One Way Anova (Analysis of Variance). The results show that CR, QR, CaR, DER, $D A R, C C R, I C R, R O A, P T O$, and TATO have undergone significant changes since the issuance of regulations. Meanwhile, the GPM, NPM, ROE, BEP, ITO, and $\mathrm{RTO}$ has not changed significantly since the issuance of the regulation.

Keywords: financial performance, liquidity ratio, solvability ratio, profitability ratio, activity ratio

$\begin{array}{ll}\text { How to cite: } & \text { Inayatullah, M. R., \& Mulyana, B. (2021) Kinerja Keuangan Perusahaan Industri Baja Nasional } \\ & \text { Sebelum dan Sesudah Diterbitkannya Peraturan Menteri Perdagangan No. 22 Tahun 2018. Syntax Idea, } \\ & \text { 3(9), https://doi.org/10.36418/syntax-idea.v3i9.1461 } \\ \text { E-ISSN: } & \text { 2684-883X } \\ \text { Published by: } & \text { Ridwan Institute }\end{array}$


Received: 2021-08-22; Accepted: 2021-09-05; Published: 2021-09-20

\section{Pendahuluan}

Dalam rangka meningkatkan laju pertumbuhan ekonomi melalui pengembangan proyek infrastruktur di tanah air, Pemerintah menggalakkan pembangunan proyekproyek yang dianggap strategis dan mempunyai kepentingan yang mendesak untuk segera direalisasikan secepatnya. Rencana pembangunan nasional yang dicakup dalam Perpres No. 56 tahun 2018 di antaranya adalah pembangunan infrastruktur jalan raya, bandar udara, pelabuhan baru, kapal penyeberangan baru, dan transportasi masal di kota-kota besar. Selain itu direncanakan juga untuk membangun waduk dan jalur kereta api yang diperkirakan membutuhkan besi dan baja sebesar 21,87 juta ton sampai dengan tahun 2025.

Melihat kondisi di atas, pemerintah melalui Kementerian Perdagangan mengeluarkan peraturan No. 22 tentang tata niaga impor besi dan baja. Tujuan utama dari dikeluarkannya Permendag ini adalah untuk penyederhanaan regulasi dan pengawasan tata niaga impor dengan cara melakukan pergeseran pengawasan Larangan Terbatas (Lartas) Impor dari Border ke Post Border. Hal ini berarti bahwa pihak Bea Cukai melakukan pemeriksaan dokumen persyaratan impor setelah melewati Kawasan Pabean. Penyederhanaan ini diharapkan dapat memperlancar proses masuknya barang.

Dikutip dari harian online Kontan pada 21 Maret 2019, di sisi lain diterbitkannya Permendag No. 22 tersebut malah dimanfaatkan importir untuk mengimpor baja dengan cara mengubah Harmonized System (HS) dari baja jenis carbon steel menjadi jenis alloy steel. Hal ini semata-mata dilakukan untuk menghindari proses post border inspection yang dilakukan oleh pihak Bea dan Cukai agar tidak terkena pembayaran bea masukHal tersebut membuat produk baja buatan dalam negeri tidak bisa bersaing karena harga baja impor lebih murah daripada produk baja lokal. Pada akhirnya sepanjang tahun 2018 sampai dengan tahun 2019 banyak perusahaan baja nasional yang gulung tikar karena tidak mampu lagi bersaing dengan produk impor yang membanjiri pasaran. Tak terkecuali bagi beberapa perusahaan terbuka yang mengalami penurunan penjualan dan keuntungan yang tidak sedikit. Di bawah ini informasi mengenai keuntungan bersih perusahaan baja nasional periode tahun 2016 sampai dengan 2019:

Tabel 1

Keuntungan bersih perusahaan sampel (dalam juta Rupiah)

\begin{tabular}{lrrrr}
\hline $\begin{array}{c}\text { Nama Perusahaan } \\
\text { (Tbk) }\end{array}$ & Tahun 2016 & Tahun 2017 & Tahun 2018 & $\begin{array}{c}\text { Tahun } \\
\mathbf{2 0 1 9}\end{array}$ \\
\hline $\begin{array}{l}\text { Beton Jaya } \\
\text { Manunggal }\end{array}$ & $(5,975)$ & 11,371 & 27,813 & 1,368 \\
\hline $\begin{array}{l}\text { Gunawan Dianjaya } \\
\text { Steel }\end{array}$ & 31,705 & 10,285 & $(87,799)$ & 26,807 \\
\hline $\begin{array}{l}\text { Jakarta Kyoei Steel } \\
\text { Work }\end{array}$ & $(2,895)$ & $(3,925)$ & $(48,588)$ & $(1,391)$ \\
\hline Krakatau Steel & $(2,428,181)$ & & & \\
\hline
\end{tabular}




\begin{tabular}{|c|c|c|c|c|}
\hline $\begin{array}{c}\text { Nama Perusahaan } \\
\text { (Tbk) }\end{array}$ & Tahun 2016 & Tahun 2017 & Tahun 2018 & $\begin{array}{c}\text { Tahun } \\
2019\end{array}$ \\
\hline (Persero) & & $(1,166,442)$ & $(2,426,031)$ & $(7,025,426)$ \\
\hline Pelangi Indah & & & & \\
\hline Canindo & 13,753 & 16,824 & 15,730 & 7,487 \\
\hline Pelat Timah & & & & \\
\hline Nusantara & 33,895 & 18,443 & $(22,290)$ & 37,532 \\
\hline $\begin{array}{l}\text { Saranacentral } \\
\text { Bajatama }\end{array}$ & 34,393 & $(22,985)$ & $(96,696)$ & 1,113 \\
\hline $\begin{array}{l}\text { Steel Pipe Industry of } \\
\text { Indonesia }\end{array}$ & 1,385 & 117 & 707 & 2,600 \\
\hline
\end{tabular}

Dari tabel di 1 tampak bahwa pada tahun 2018 khususnya hampir semua perusahaan mengalami penurunan keuntungan bersih cukup tajam sejak dikeluarkannya Permendag No. 22 di awal tahun 2018. Membanjirnya produk impor membuat perusahaan menurunkan kapasitas produksinya. Selain itu beberapa perusahaan juga menghentikan beberapa jenis produksi baja karena kalah bersaing dengan produk impor dan juga kehilangan permintaan dari pasar.

Gambaran di atas menginformasikan adanya perbedaan kinerja keuangan sebelum dan sesudah diterbitkannya Permendag No. 22 tahun 2018. Menurut Sawir (2005:1) kinerja keuangan dapat diartikan sebuah situasi yang menggambarkan kondisi keuangan suatu perusahaan berdasarkan target, tolok ukur, dan indikator yang telah ditetapkan.

Kondisi keuangan dan kesehatan suatu perusahaan pada periode waktu tertentu bisa digambarkan melalui kinerja keuangan. Pengukuran kinerja keuangan dapat dianggap sebagai tindakan yang konvensional yang mengarah kepada keberlanjutan perusahaan yang oleh karena itu perlu dikelola dan dikendalikan dengan baik.

Penelitian yang dilakukan oleh Solikhah, Susyanti, dan Wahono (2017) menyebutkan bahwa terdapat perbedaan yang signifikan pada Net Profit Margin dan Total Asset Turnover sebelum dan selama diberlakukannya Peraturan Pemerintah No. 34 tahun 2016 dalam bidang properti. Namun tidak terdapat perbedaan yang signifikan pada Quick Ratio, Current Ratio, Debt to Asset Ratio, Debt to Equity Ratio, Return on Asset, dan Return on Equity.

Berdasarkan paparan di atas maka maksud dibuatnya tulisan ini adalah menganalisa kinerja keuangan perusahaan industri besi baja yang terdampak langsung oleh terbitnya Permendag No. 22 tahun 2018 dengan waktu pengamatan dari tahun 2016 sampai dengan 2019. Analisis dalam penelitian ini menggunakan pendekatan rasio keuangan.

\section{Metode Penelitian}

Jenis penelitian ini adalah deskriptif-komparatif yaitu perpaduan dua metode yakni metode deskriptif dan metode komparatif. Tujuan dari penelitian deskriptif ini adalah penggambaran karakteristik populasi atau fenomena yang sedang diteliti. Metode ini berfokus untuk menjelaskan obyek penelitiannya agar bisa menjawab 
fenomena yang sedang terjadi. Sedangkan metode komparatif secara sederhana adalah tindakan membandingkan dua atau lebih hal dengan maksud untuk menemukan sesuatu tentang satu atau semua hal yang yang dibandingkan.

Data yang digunakan dalam penelitian ini adalah data kuantitatif, sekunder, dan time series, dan cross section.

Metode analisis data yang dipakai dalam penelitian ini meliputi:

1. Analisa deskriptif adalah jenis analisis data yang membantu menggambarkan, menunjukkan, atau meringkas titik-titik data dengan cara yang konstruktik sehingga pola-pola yang mungkin muncul memenuhi setiap kondisi data dengan melihat nilai rata-rata.

2. Uji hipotesis menggunakan One Way Anova (Analysis of Variance) yang membandingkan rata-rata dari dua atau lebih kelompok independen untuk menentukan apakah ada bukti statistik bahwa rata-rata populasi terkait berbeda secara signifikan.

\section{Hasil dan Pembahasan}

1. Statistik Deskriptif

1) Statistik Deskriptif Rasio Likuiditas

Hasil perhitungan rata-rata rasio likuiditas yang terdiri dari 3 variabel yaitu Current Ratio, Quick Ratio, dan Cash Ratio 2 tahun sebelum (tahun 2016 dan 2017) dan 2 tahun sesudah (2018 dan 2019) diterbitkannya Permendag No. 22 tahun 2018 pada 8 perusahaan sampel menunjukkan hasil sebagai berikut:

Tabel 2

Hasil perhitungan rata-rata rasio likuiditas

\begin{tabular}{cccc}
\hline $\begin{array}{c}\text { Variabel yang } \\
\text { dipakai }\end{array}$ & $\begin{array}{c}\text { Rata-rata } \\
\text { sebelum }\end{array}$ & $\begin{array}{c}\text { Rata-rata } \\
\text { sesudah }\end{array}$ & Catatan \\
\hline Current Ratio & $177 \%$ & $166 \%$ & $\begin{array}{c}\text { Turun, } \\
\text { memburuk }\end{array}$ \\
\hline Quick Ratio & $116 \%$ & $271 \%$ & Naik, membaik \\
\hline Cash Ratio & $67 \%$ & $66 \%$ & $\begin{array}{c}\text { Turun, } \\
\text { memburuk }\end{array}$ \\
\hline
\end{tabular}

Hasil perhitungan Current Ratio menunjukkan bahwa ada penurunan sebesar $11 \%$ yang menunjukkan bahwa kemampuan perusahaan untuk melunasi hutang jangka pendek dengan menggunakan aktiva lancarnya menurun.

Di sisi lain dari hasil perhitungan Quick Ratio ada kenaikan sebesar 155\% yang mengindikasikan bahwa kemampuan perusahaan melunasi hutang jangka pendek dengan menggunakan aktiva lancar dikurangi persediaan naik.

Sedangkan dari perhitungan Cash Ratio memperlihatkan adanya penurunan sebesar $1 \%$ yang menunjukkan bahwa kemampuan perusahaan untuk melunasi hutangnya dengan menggunakan kas mengalami penurunan. 
Secara keseluruhan dari perhitungan rasio likuiditas dapat dikatakan bahwa sesudah terbitnya Permendag No. 22 tahun 2018 ada penurunan kemampuan perusahaan dalam memenuhi hutang jangka pendeknya.

2) Statistik Deskriptif Rasio Solvabilitas

Hasil perhitungan rata-rata rasio solvabilitas yang terdiri dari 4 variabel yaitu Debt to Equity Ratio, Debt to Asset Ratio, Cash Coverage Ratio, dan Interest Coverage Ratio 2 tahun sebelum (tahun 2016 dan 2017) dan 2 tahun sesudah (2018 dan 2019) diterbitkannya Permendag No. 22 tahun 2018 pada 8 perusahaan sampel menunjukkan hasil sebagai berikut:

Tabel 3

Hasil perhitungan rata-rata rasio solvabilitas

\begin{tabular}{cccc}
\hline $\begin{array}{c}\text { Variabel yang } \\
\text { dipakai }\end{array}$ & $\begin{array}{c}\text { Rata-rata } \\
\text { sebelum }\end{array}$ & $\begin{array}{c}\text { Rata-rata } \\
\text { sesudah }\end{array}$ & Catatan \\
\hline Debt to Equity Ratio & $124 \%$ & $120 \%$ & Turun, membaik \\
\hline Debt to Asset Ratio & $80 \%$ & $99 \%$ & Naik, memburuk \\
\hline Cash Coverage Ratio & $183 \%$ & $-12 \%$ & Turun, memburuk \\
\hline $\begin{array}{c}\text { Interest Coverage } \\
\text { Ratio }\end{array}$ & $83 \%$ & $-85 \%$ & Turun, memburuk \\
\hline
\end{tabular}

Hasil perhitungan Debt to Equity Ratio memperlihatkan bahwa ada penurunan sebesar 4\%. Hal itu menunjukkan bahwa adanya pengurangan hutang sehingga resiko pelunasan hutang dengan menggunakan modal bisa diperkecil.

Pada perhitungan Debt to Asset Ratio memperlihatkan adanya kenaikan sebesar $19 \%$. Hal itu mengindikasikan bahwa jumlah aset yang dibiayai oleh hutang semakin tinggi. Semakin tinggi hutang, maka semakin tinggi resiko penyelesaiannya.

Sedangkan pada perhitungan Cash Coverage Ratio terlihat adanya penurunan sebesar $195 \%$. Hal ini menunjukkan bahwa kemampuan perusahaan menggunakan laba sebelum dan pajak (EBIT) ditambah dengan penyusutan untuk memenuhi kewajiban kepada kreditor mengalami penurunan yang cukup drastis. Bisa dikatakan bahwa pendapatan perusahaan tidak cukup untuk menutupi biaya bunga.

Hal yang sama juga terjadi pada perhitungan Interest Coverage Ratio yang menunjukkan penurunan sebesar $102 \%$ setelah diterbitkannya peraturan. Hal ini memperlihatkan bahwa kemampuan perusahaan membayar kewajiban kepada kreditor dengan menggunakan laba sebelum bunga dan pajak dalam bentuk bunga turun secara signifikan.

3) Statistik Deskriptif Rasio Profitabilitas

Hasil perhitungan rata-rata rasio profitabilitas yang terdiri dari 5 variabel yaitu Gross Profit Margin, Net Profit Margin, Return on Asset, Return on Equity, dan Basic Earning Power 2 tahun sebelum (tahun 2016 dan 2017) dan 2 tahun sesudah (2018 dan 2019) diterbitkannya Permendag No. 22 tahun 2018 pada 8 perusahaan sampel menunjukkan hasil sebagai berikut: 
Tabel 4

Hasil Perhitungan Rata-Rata Rasio Profitabilitas

\begin{tabular}{lrrl}
\hline $\begin{array}{c}\text { Variabel yang } \\
\text { dipakai }\end{array}$ & $\begin{array}{c}\text { Rata-rata } \\
\text { sebelum }\end{array}$ & $\begin{array}{c}\text { Rata-rata } \\
\text { sesudah }\end{array}$ & \multicolumn{1}{c}{ Catatan } \\
\hline Gross Profit Margin & $10 \%$ & $11 \%$ & Naik, membaik \\
\hline Net Profit Margin & $0 \%$ & $-3 \%$ & Turun, memburuk \\
\hline Return On Asset & $7 \%$ & $5 \%$ & Turun, memburuk \\
\hline Return On Equity & $2 \%$ & $-16 \%$ & Turun, memburuk \\
\hline $\begin{array}{l}\text { Basic Earning } \\
\text { Power }\end{array}$ & $1 \%$ & $-2 \%$ & Turun, memburuk \\
\hline
\end{tabular}

Hasil perhitungan rata-rata Gross Profit Margin memperlihatkan bahwa ada kenaikan $1 \%$. Hal ini menunjukkan tetap bisa meraih laba operasional setelah diterbitkannya peraturan.

Sedangkan pada perhitungan Net Profit Margin memperlihatkan adanya penurunan 3\%. Hal ini mengindikasikan bahwa 2 tahun setelah diterbitkannya peraturan, perusahaan tidak dapat mencetak laba bersih dari penjualannya lebih baik. Hal yang sama juga ditunjukkan perhitungan Return on Asset yang juga menunjukkan penurunan sebesar $2 \%$. Kemampuan perusahaan untuk memperoleh laba dengan menggunakan asetnya turun sejak diterbitkannya peraturan.

Selain itu perhitungan Return on Equity menunjukkan penurunan sebesar 18\%. Hal itu memperlihatkan kemampuan perusahaan menghasilkan laba bersih dengan menggunakan modal yang dimiliki mengalami penurunan. Dan yang terakhir, hasil perhitungan Basic Earning Power menunjukkan penurunan sebesar $3 \%$. Penurunan ini menunjukkan kemampuan perusahaan untuk menghasilkan laba sebelum bunga dan pajak dengan menggunakan total aktiva yang dimiliki perusahaan.

4) Statistik Deskriptif Rasio Aktivitas

Hasil perhitungan rata-rata rasio aktivitas yang terdiri dari 4 variabel yaitu Inventory Turnover, Receivable Turnover, Payable Turnover, dan Total Asset Turnover 2 tahun sebelum (tahun 2016 dan 2017) dan 2 tahun sesudah (2018 dan 2019) diterbitkannya Permendag No. 22 tahun 2018 pada 8 perusahaan sampel menunjukkan hasil sebagai berikut:

Tabel 5

Hasil perhitungan rata-rata rasio aktivitas

\begin{tabular}{lccl}
\hline $\begin{array}{c}\text { Variabel yang } \\
\text { dipakai }\end{array}$ & $\begin{array}{c}\text { Rata-rata } \\
\text { sebelum }\end{array}$ & $\begin{array}{c}\text { Rata-rata } \\
\text { sesudah }\end{array}$ & \multicolumn{1}{c}{ Catatan } \\
\hline Inventory Turnover & $412 \%$ & $414 \%$ & Naik, membaik \\
\hline Receivable Turnover & $605 \%$ & $14.674 \%$ & Naik, membaik \\
\hline Payable Turnover & $771 \%$ & $839 \%$ & Naik, membaik \\
\hline Total Asset Turnover & $75 \%$ & $76 \%$ & Naik, membaik \\
\hline
\end{tabular}


Dari hasil perhitungan Inventory Turnover terlihat ada kenaikan sebesar 2\% yang mengindikasikan bahwa perputaran persediaan menjadi penjualan berjalan lebih cepat. Hal ini menunjukkan efisiensi perusahaan dalam mengelola persediaannya.

Selain itu kenaikan juga terjadi pada Receivable Turnover yang naik signifikan sebesar $14.069 \%$. Kenaikan ini menunjukkan kemampuan perusahaan dalam menagih piutang kepada pelanggan naik lebih baik.

Sementara itu dari perhitungan Payable Turnover tampak ada kenaikan sebesar $68 \%$ yang menunjukkan bahwa kemampuan perusahaan meningkat dalam melunasi hutang jangka pendek kepada para pemasoknya. Kenaikan juga terjadi Total Asset Turnover sebesar 1\% yang mengindikasikan bahwa kemampuan perusahaan meningkat dalam menghasilkan penjualan dengan menggunakan aset yang dimiliki 2 tahun setelah diterbitkannya peraturan.

Secara keseluruhan perhitungan dengan rasio aktivitas menunjukkan adanya perbaikan setelah diterbitkannya Permendag No. 22.

2. One Way Anova (Analysis of Variance)

Analisa data ini menggunakan pendekatan One Way Anova karena dengan pendekatan ini diperoleh perbedaan dan signifikansi perbedaan tersebut. Pengujian dilakukan untuk menguji perbedaan rata-rata data lebih dari kelompok dengan tingkat signfikansi paling banyak 5\%. Dalam hal ini ada risiko kesalahan sebanyak persentase tersebut (5\%) ketika mengambil keputusan. Pengujian dilakukan dengan menggunakan software SPSS 25.

1) Rasio Likuiditas

Berikut ini hasil perhitungan rasio likuiditas dengan menggunakan One Way Anova untuk menguji perbedaan mean (rata-rata) sebelum dikeluarkannya Permendag No. 22 (tahun 2016 dan 2017) dan sesudah dikeluarkannya Permendag No. 22 (tahun 2018 dan 2019):

Tabel 6

Hasil Perhitungan One Way Anova terhadap rasio likuiditas

\begin{tabular}{llrrrrr}
\hline Variabel & & $\begin{array}{c}\text { Sum of } \\
\text { Squares }\end{array}$ & df & $\begin{array}{r}\text { Mean } \\
\text { Square }\end{array}$ & F & Sig. \\
\hline Current Ratio & Between & 2.407 & 7 & 0.344 & 30.184 & 0.000 \\
& Groups & & & & & \\
\hline & Within Groups & 0.273 & 24 & 0.011 & & \\
\hline & Total & 2.680 & 31 & & & \\
\hline & Between & 4.925 & 7 & 0.704 & 48.786 & 0.000 \\
\hline & Groups & & & & & \\
\hline & Within Groups & 0.346 & 24 & 0.014 & & \\
\hline & Total & 5.271 & 31 & & & \\
\hline & Between & 60.573 & 7 & 8.653 & 171.377 & 0.000 \\
\hline & Groups & & & & & \\
\hline & Within Groups & 1.212 & 24 & 0.050 & & \\
\hline
\end{tabular}


1) Berdasarkan output di atas diperoleh nilai probabilitas signifikansi (Sig.) sebesar $0,000<0,05$ yang berarti terdapat perbedaan yang signifikan sebelum dan sesudah diterbitkannya Permendag No. 22 terhadap variabel Current Ratio.

2) Berdasarkan output di atas diperoleh nilai probabilitas signifikansi (Sig.) sebesar $0,000<0,05$ yang berarti terdapat perbedaan yang signifikan sebelum dan sesudah diterbitkannya Permendag No. 22 terhadap Quick Ratio.

3) Berdasarkan output di atas diperoleh nilai probabilitas signifikansi (Sig.) sebesar $0,000<0,05$ yang berarti terdapat perbedaan yang signifikan sebelum dan sesudah diterbitkannya Permendag No. 22 terhadap Cash Ratio.

2) Rasio Solvabilitas

Berikut ini hasil perhitungan rasio solvabilitas dengan menggunakan One

Way Anova untuk menguji perbedaan mean (rata-rata) sebelum dikeluarkannya Permendag No. 22 (tahun 2016 dan 2017) dan sesudah dikeluarkannya Permendag No. 22 (tahun 2018 dan 2019):

\section{Tabel 7}

Hasil Perhitungan One Way Anova terhadap rasio solvabilitas

\begin{tabular}{|c|c|c|c|c|c|c|}
\hline \multicolumn{2}{|l|}{ Variabel } & \multirow{2}{*}{$\begin{array}{r}\begin{array}{c}\text { Sum of } \\
\text { Squares }\end{array} \\
5.509\end{array}$} & \multirow{3}{*}{$\begin{array}{r}\text { df } \\
6\end{array}$} & \multirow{2}{*}{$\begin{array}{r}\begin{array}{c}\text { Mean } \\
\text { Square }\end{array} \\
0.918\end{array}$} & \multirow{2}{*}{$\begin{array}{c}\mathbf{F} \\
24.964\end{array}$} & \multirow{2}{*}{$\begin{array}{l}\text { Sig. } \\
0.000\end{array}$} \\
\hline Debt to & Between & & & & & \\
\hline \multirow{3}{*}{ Equity Ratio } & Groups & & & & & \\
\hline & Within Groups & 0.772 & 21 & 0.037 & & \\
\hline & Total & 6.281 & 27 & & & \\
\hline \multirow{4}{*}{$\begin{array}{l}\text { Debt to Asset } \\
\text { Ratio }\end{array}$} & Between & 3.477 & 7 & 0.497 & 134.205 & 0.000 \\
\hline & Groups & & & & & \\
\hline & Within Groups & 0.089 & 24 & 0.004 & & \\
\hline & Total & 3.566 & 31 & & & \\
\hline \multirow{4}{*}{$\begin{array}{l}\text { Cash } \\
\text { Coverage } \\
\text { Ratio }\end{array}$} & Between & 37.088 & 6 & 6.181 & 3.504 & 0.021 \\
\hline & Groups & & & & & \\
\hline & Within Groups & 28.225 & 16 & 1.764 & & \\
\hline & Total & 65.313 & 22 & & & \\
\hline \multirow{4}{*}{$\begin{array}{l}\text { Interest } \\
\text { Coverage } \\
\text { Ratio }\end{array}$} & Between & 16.524 & 5 & 3.305 & 4.607 & 0.016 \\
\hline & Groups & & & & & \\
\hline & Within Groups & 7.892 & 11 & 0.717 & & \\
\hline & Total & 24.416 & 16 & & & \\
\hline
\end{tabular}

1) Berdasarkan output di atas diperoleh nilai probabilitas signifikansi (Sig.) sebesar $0,000<0,05$ yang berarti terdapat perbedaan yang signifikan sebelum dan sesudah diterbitkannya Permendag No. 22 terhadap Debt to Equity Ratio.

2) Berdasarkan output di atas diperoleh nilai probabilitas signifikansi (Sig.) sebesar $0,000<0,05$ yang berarti terdapat perbedaan yang signifikan sebelum dan sesudah diterbitkannya Permendag No. 22 terhadap Debt to Asset Ratio.

3) Berdasarkan output di atas diperoleh nilai probabilitas signifikansi (Sig.) sebesar $0,021<0,05$ yang berarti terdapat perbedaan yang signifikan sebelum dan sesudah diterbitkannya Permendag No. 22 terhadap Cash Coverage Ratio. 
4) Berdasarkan output di atas diperoleh nilai probabilitas signifikansi (Sig.) sebesar 0,016< 0,05 yang berarti terdapat perbedaan yang signifikan sebelum dan sesudah diterbitkannya Permendag No. 22 terhadap Interest Coverage Ratio.

3) Rasio Profitabilitas

Berikut ini hasil perhitungan rasio provitabilitas dengan menggunakan One Way Anova untuk menguji perbedaan mean (rata-rata) sebelum dikeluarkannya Permendag No. 22 (tahun 2016 dan 2017) dan sesudah dikeluarkannya Permendag No. 22 (tahun 2018 dan 2019):

\section{Tabel 8}

Hasil perhitungan One Way Anova terhadap rasio profitabilitas

\begin{tabular}{|c|c|c|c|c|c|c|}
\hline Variabel & & $\begin{array}{l}\text { Sum of } \\
\text { Squares }\end{array}$ & df & $\begin{array}{c}\text { Mean } \\
\text { Square }\end{array}$ & $\mathbf{F}$ & Sig. \\
\hline \multirow{5}{*}{$\begin{array}{l}\text { Gross Profit } \\
\text { Margin }\end{array}$} & Between & 0.053 & 7 & 0.008 & 1.122 & 0.385 \\
\hline & Groups & & & & & \\
\hline & Within & 0.150 & 22 & 0.007 & & \\
\hline & Groups & & & & & \\
\hline & Total & 0.203 & 29 & & & \\
\hline \multirow{5}{*}{$\begin{array}{l}\text { Net Profit } \\
\text { Margin }\end{array}$} & Between & 480.219 & 7 & 68.603 & 1.954 & 0.105 \\
\hline & Groups & & & & & \\
\hline & Within & 842.750 & 24 & 35.115 & & \\
\hline & Groups & & & & & \\
\hline & Total & 1322.969 & 31 & & & \\
\hline \multirow{4}{*}{$\begin{array}{l}\text { Return On } \\
\text { Asset }\end{array}$} & Between & 394.969 & 7 & 56.424 & 5.244 & 0.001 \\
\hline & Groups & & & & & \\
\hline & $\begin{array}{l}\text { Within } \\
\text { Groups }\end{array}$ & 258.250 & 24 & 10.760 & & \\
\hline & Total & 653.219 & 31 & & & \\
\hline \multirow{5}{*}{$\begin{array}{l}\text { Return On } \\
\text { Equity }\end{array}$} & Between & 10050.875 & 7 & 1435.839 & 1.316 & 0.285 \\
\hline & Groups & & & & & \\
\hline & Within & 26177.000 & 24 & 1090.708 & & \\
\hline & Groups & & & & & \\
\hline & Total & 36227.875 & 31 & & & \\
\hline \multirow{5}{*}{$\begin{array}{l}\text { Basic } \\
\text { Earning } \\
\text { Power }\end{array}$} & Between & 0.010 & 5 & 0.002 & 1.830 & 0.176 \\
\hline & Groups & & & & & \\
\hline & Within & 0.014 & 13 & 0.001 & & \\
\hline & Groups & & & & & \\
\hline & Total & 0.023 & 18 & & & \\
\hline
\end{tabular}

1) Berdasarkan output di atas diperoleh nilai probabilitas signifikansi (Sig.) sebesar 0,385>0,05 yang berarti tidak terdapat perbedaan yang signifikan sebelum dan sesudah diterbitkannya Permendag No. 22 terhadap Gross Profit Margin.

2) Berdasarkan output di atas diperoleh nilai probabilitas signifikansi (Sig.) sebesar $0,105>0,05$ yang berarti tidak terdapat perbedaan yang signifikan sebelum dan sesudah diterbitkannya Permendag No. 22 terhadap Net Profit Margin. 
3) Berdasarkan output di atas diperoleh nilai probabilitas signifikansi (Sig.) sebesar $0,001<0,05$ yang berarti terdapat perbedaan yang signifikan sebelum dan sesudah diterbitkannya Permendag No. 22 terhadap Return on Asset.

4) Berdasarkan output di atas diperoleh nilai probabilitas signifikansi (Sig.) sebesar $0,285>0,05$ yang berarti tidak terdapat perbedaan yang signifikan sebelum dan sesudah diterbitkannya Permendag No. 22 terhadap Return on Equity.

5) Berdasarkan output di atas diperoleh nilai probabilitas signifikansi sebesar 0,176>0,05 yang berarti tidak terdapat perbedaan yang signifikan sebelum dan sesudah diterbitkannya Permendag No. 22 terhadap Basic Earning Power.

4) Rasio Aktivitas

Berikut ini hasil perhitungan rasio aktivitas dengan menggunakan One Way Anova untuk menguji perbedaan mean (rata-rata) sebelum dikeluarkannya Permendag No. 22 (tahun 2016 dan 2017) dan sesudah dikeluarkannya Permendag No. 22 (tahun 2018 dan 2019):

Tabel 9

Hasil perhitungan One Way Anova terhadap rasio aktivitas

\begin{tabular}{|c|c|c|c|c|c|c|}
\hline Variabel & & $\begin{array}{l}\text { Sum of } \\
\text { Squares }\end{array}$ & df & $\begin{array}{c}\text { Mean } \\
\text { Square }\end{array}$ & $\mathbf{F}$ & Sig. \\
\hline \multirow[t]{3}{*}{$\begin{array}{l}\text { Inventory } \\
\text { Turnover }\end{array}$} & $\begin{array}{l}\text { Between } \\
\text { Groups }\end{array}$ & 105.584 & 7 & 15.083 & 1.702 & 0.156 \\
\hline & $\begin{array}{l}\text { Within } \\
\text { Groups }\end{array}$ & 212.630 & 24 & 8.860 & & \\
\hline & Total & 318.214 & 31 & & & \\
\hline \multirow[t]{3}{*}{$\begin{array}{l}\text { Receivable } \\
\text { Turnover }\end{array}$} & $\begin{array}{c}\text { Between } \\
\text { Groups }\end{array}$ & 962201.207 & 7 & 137457.315 & 0.998 & 0.457 \\
\hline & $\begin{array}{l}\text { Within } \\
\text { Groups }\end{array}$ & 3305988.805 & 24 & 137749.534 & & \\
\hline & Total & 4268190.012 & 31 & & & \\
\hline \multirow[t]{3}{*}{$\begin{array}{l}\text { Payable } \\
\text { Turnover }\end{array}$} & $\begin{array}{c}\text { Between } \\
\text { Groups }\end{array}$ & 1661.475 & 7 & 237.354 & 5.749 & 0.001 \\
\hline & $\begin{array}{l}\text { Within } \\
\text { Groups }\end{array}$ & 990.835 & 24 & 41.285 & & \\
\hline & Total & 2652.310 & 31 & & & \\
\hline \multirow[t]{3}{*}{$\begin{array}{l}\text { Total Asset } \\
\text { Turnover }\end{array}$} & $\begin{array}{l}\text { Between } \\
\text { Groups }\end{array}$ & 36568.969 & 7 & 5224.138 & 11.488 & 0.000 \\
\hline & $\begin{array}{l}\text { Within } \\
\text { Groups }\end{array}$ & 10913.750 & 24 & 454.740 & & \\
\hline & Total & 47482.719 & 31 & & & \\
\hline
\end{tabular}

(1) Berdasarkan output di atas diperoleh nilai probabilitas signifikansi (Sig.) sebesar 0,156>0,05 yang berarti tidak terdapat perbedaan yang signifikan sebelum dan sesudah diterbitkannya Permendag No. 22 terhadap Inventory Turnover. 
(2) Berdasarkan output di atas diperoleh nilai probabilitas signifikansi (Sig.) sebesar 0,457>0,05 yang berarti tidak terdapat perbedaan yang signifikan sebelum dan sesudah diterbitkannya Permendag No. 22 terhadap Receivable Turnover.

(3) Berdasarkan output di atas diperoleh nilai probabilitas signifikansi (Sig.) sebesar $0,001<0,05$ yang berarti terdapat perbedaan yang signifikan sebelum dan sesudah diterbitkannya Permendag No. 22 terhadap Payable Turnover.

(4) Berdasarkan output di atas diperoleh nilai probabilitas signifikansi (Sig.) sebesar $0,000<0,05$ yang berarti terdapat perbedaan yang signifikan sebelum dan sesudah diterbitkannya Permendag No. 22 terhadap Total Asset Turnover.

Hasil pengujian dengan One Way Anova menunjukkan terdapat perbedaan signifikan pada beberapa variabel dan juga tidak terdapat perbedaan signifikan pada beberapa variabel yang dapat diringkas pada Tabel 10 berikut.

Tabel 10

Hasil Pengujian One Way Anova

\begin{tabular}{llcc}
\hline Kode & \multicolumn{1}{c}{ Hipotesis } & Variabel & Kesimpulan \\
\hline $\mathrm{H}_{1}$ & Terdapat perbedaan signifikan pada & Current Ratio & Diterima \\
\cline { 3 - 4 } & Rasio Likuiditas sebelum dan & Quick Ratio & Diterima \\
\cline { 3 - 4 } & sesudah terbitnya Permendag No. 22 & Cash Ratio & Diterima \\
\hline $\mathrm{H}_{2}$ & Terdapat perbedaan signifikan pada & Debt to Equity Ratio & Diterima \\
\cline { 3 - 4 } & Rasio Solvabilitas sebelum dan & Debt to Asset Ratio & Diterima \\
\cline { 3 - 4 } & sesudah terbitnya Permendag No. 22 & Cash Coverage Ratio & Diterima \\
\cline { 3 - 4 } & & Interest Coverage & Diterima \\
\hline $\mathrm{H}_{3}$ & Terdapat perbedaan signifikan pada & Rross Profit Margin & Ditolak \\
\cline { 3 - 4 } & Rasio Profitabilitas sebelum dan & Net Profit Margin & Ditolak \\
\cline { 3 - 4 } & sesudah terbitnya Permendag No. 22 & Return On Asset & Diterima \\
\cline { 3 - 4 } & & Return On Equity & Ditolak \\
\cline { 3 - 4 } & Terdapat perbedaan signifikan pada & Basic Earning Power & Ditolak \\
\cline { 3 - 4 } $\mathrm{H}_{4}$ & Rasio Aktivitas sebelum dan & Receivable Turnover & Ditolak \\
\cline { 3 - 4 } & sesudah terbitnya Permendag No. 22 & Payable Turnover & Diterima \\
\cline { 3 - 4 } & & Total Asset Turnover & Diterima \\
\hline
\end{tabular}

\section{Kesimpulan}

Berdasarkan hasil penelitian dengan menggunakan statistik deskriptif dan One Way Anova maka dapat diambil kesimpulan sebagai berikut: Pertama, Terdapat peningkatan pada Quick Ratio, Debt to Asset Ratio, Gross Profit Ratio, Inventory Turnover, Receivable Turnover, Payable Turnover, dan Total Asset Turnover sesudah diterbitkannya Permendag No. 22 tahun 2018. Terdapat penurunan pada Current Ratio, Cash Ratio, Debt to Equity Ratio, Cash Coverage Ratio, Interest Coverage Ratio, Net Profit Margin, Return on Asset, Return on Equity, dan Basic Earning Power sesudah diterbitkannya Permendag No. 22 tahun 2018. Kedua, Terdapat perbedaan yang 
Kinerja Keuangan Perusahaan Industri Baja Nasional Sebelum dan Sesudah Diterbitkannya Peraturan Menteri Perdagangan No. 22 Tahun 2018

signifikan sesudah terbitnya Permendag No. 22 terhadap Current Ratio, Quick Ratio, Cash Ratio, Debt to Equity Ratio, Debt to Asset Ratio, Cash Coverage Ratio, Interest Coverage Ratio, Return on Asset, Payable Turnover, dan Total Asset Turnover. Tidak terdapat perbedaan yang signifikan sesudah terbitnya Permendag No. 22 terhadap Gross Profit Margin, Net Profit Margin, Return on Equity, Basic Earning Power, Inventory Turnover, dan Receivable Turnover 


\section{BIBLIOGRAFI}

Alanazi, A. S., Liu, B., \& Forster, J. (2011). The financial performance of Saudi Arabian IPOs. International Journal of Islamic and Middle Eastern Finance and Management. Google Scholar

Allfian, Ayu D. \& Triyonowati, (2015). Analisis Perbedaan Kinerja Keuangan Sebelum dan Sesudah Akuisisi Pada PT. Jasa Marga, Tbk., Jurnal Ilmu dan Riset Manajemen. Google Scholar

Anthony, M.U.G.O. (2017). Effects of merger and acquisition on financial performance: case study of commercial banks. International Journal of Business Management \& Finance, 1(6), 93-105. Google Scholar

Anwar, Mokhamad. (2019) Dasar-dasar Manajemen Keuangan. Edisi Pertama. Kencana. Jakarta. Google Scholar

Aprilita, I., \& Dp, R. T. (2013). Analisis Perbandingan Kinerja Keuangan Perusahaan Sebelum dan Sesudah Akuisisi (Study pada Perusahaan Pengakuisisi yang Terdaftar di BEI Periode 2000-2011). Jurnal Manajemen dan Bisnis Sriwijaya, 11(2), 99-113. Google Scholar

Ariani, Andewi Rokhmawati, dan Ahmad Fauzan Fathoni. (2019) Analisis Perbandingan DER, ROA, dan EVA Pada Perusahaan Pertambangan Sebelum dan Sesudah Penerapan Peraturan Pemerintah No. 1 Tahun 2014 Tentang Larangan Ekspor Mineral Mentah. Fakultas Ekonomi dan Bisnis Universitas Riau. Google Scholar

Badan Pusat Statistik. (2020) Data Impor Pipa Besi dan Baja Menurut Negara Asal Utama, 2000-2019. Publikasi Statistik Indonesia. Diunduh melalui www.bps.go.id.

Biantoro, Agung Wahyudi. (2017) Perbedaan Kinerja Keuangan Perusahaan Pengakuisisi Setelah Melakukan Merger dan Akuisisi. Jurnal Ilmiah Manajemen Bisnis, Volume 3. Diakses melalui http://digilib.mercubuana.ac.id/. Google Scholar

Dewi, S. R. (2015). Analisa Perbandingan Kinerja Keuangan BeberapaPerusahaan Sebelum dan Sesudah Akuisisi (Studi Pada Perusahaan Pengakuisisi yang Terdaftar di BEI Periode 2003-2013). Jurnal Ekonomi dan Bisnis. Universitas Dian Nuswantoro. Google Scholar

Fabiola, Puti Nadina (2020). Kinerja Keuangan PT. Aneka Gas Industri Tbk Sebelum dan Sesudah Initial Public Offering (IPO), Program Studi D3 Akuntansi, Fakultas Ekonomi Universitas Negeri Jakarta. Google Scholar

Ghozali, Imam. (2013) Aplikasi Multivariate Dengan Program SPSS. Edisi Ketujuh. Semarang: Badan Penerbit Universitas Diponegoro. Google Scholar 
Kinerja Keuangan Perusahaan Industri Baja Nasional Sebelum dan Sesudah Diterbitkannya Peraturan Menteri Perdagangan No. 22 Tahun 2018

Gunawan, Ce. (2017) Mahir Menguasai SPSS (Mudah Mengolah Data Dengan IBM SPSS Statistic 25). Penerbit Deepublish. Yogyakarta. Google Scholar

Harahap, Sofyan Syafri. (2015) Analisis Kritis Atas Laporan Keuangan. Jakarta: Raja Grafindo Persada. Google Scholar

International Trade Administration. (2019) Steel Imports Report: Indonesia. Steel Import Monitoring and Analysis. Washington, DC.

Irfan, Muhammad A. (2019) Penguatan Industri Besi-Baja Menuju Ketahanan Nasional. Investor Daily. Diakses melalui https://investor.id/opinion/

Kasmir. (2016) Analisis Laporan Keuangan, cetakan 9. PT. Rajagrafindo, Jakarta.

Kementerian Perindustrian Republik Indonesia. (2015) Profil Industri Baja 2014.

Lai, K. Y., Ling, T. P., Eng, T. K., Cheng, L. S., \& Ting, L. F. (2015). Financial Performance of Malaysia Local Banks: During Period of Pre-Merger and PostMerger. Journal of Economics, Business and Management, 3(9), 826-830. Google Scholar

Laporan Keuangan dan Tahunan, Perusahaan Tercatat Pada Bursa Efek Indonesia. Diunduh melalui https://www.idx.co.id/perusahaan-tercatat/laporan-keuangandan-tahunan/ Google Scholar

Mahesh, R., \& Prasad, D. (2012). Post-merger and acquisition financial performance analysis: A case study of select Indian airline companies. International journal of engineering and management sciences, 3(3), 362-369. Google Scholar

Menteri Perdagangan Republik Indonesia. (2018) Peraturan Menteri Perdagangan Nomor 22 Tahun 2018 Tentang Ketentuan Impor Besi atau Baja, Baja Paduan, dan Produk Turunannya.

Moctar, N. B., \& Xiaofang, C. H. E. N. (2014). The Impact of Mergers and Acquisition on the financial performance of West African Banks: A case study of some selected commercial banks. International Journal of Education and Research, 2(1), 1-10. Google Scholar

Mulyana, Bambang \& R. Eddy Nugroho. (2018) Manajemen Keuangan Perusahaan, Adhi Sarana Nusantara, Jakarta

Nalwaya, N., \& Vyas, R. (2014). Merger and Acquisition in the Telecom Industry: An Analysis of Financial Performance of Vodafone Plc and Hutchison Essar. Journal of Marketing \& Communication, 9(3). Google Scholar

Nasir, M. (2018). Analisis Perbandingan Kinerja Keuangan Pada Perusahaan Sebelum dan Sesudah Merger dan Akuisisi (Studi Perusahaan yang Melakukan Merger dan 
Akuisisi yang Terdaftar di BEI 2013-2015). Jurnal Economic Resource, 1(1), 7185.

Noviati, Marini B. (2019). Analisa Perbedaan Kinerja Keuangan Sebelum dan Sesudah Merger dan Akuisisi (Studi Empiris Pada Perusahaan Perbankan yang Terdaftar di BEI yang melakukan Merger dan Akuisisi Periode 2010-2015). Universitas Mercu Buana, Jakarta. Google Scholar

Solikhah, Mar'atus, Jeni Susyanti, dan Budi Wahono. (2016) Analisa Kinerja Keuangan Perusahaan Real Estate dan Property Sebelum dan Selama Diberlakukannya PP No. 34 Tahun 2016. Fakultas Ekonomi Unisma. Google Scholar

Sparsa I Gusti A.A., Widanaputra (2014). Analisa Kinerja Keuangan BUMN Sebelum dan Sesudah Privatisasi di Indonesia Periode 20014-2009. E-Journal Akuntansi Universitas Udayana Bali.

Suara Karya. (2020) Presiden Jokowi menyatakan kekecewaan mengapa impor baja masih tinggi. Diakses melalui https://www.suarakarya.id/detail/107106/. Google Scholar

Sudana, I Made (2011) Manajemen Keuangan Perusahaan Teori dan Praktik. Edisi 2, Penerbit Erlangga, Jakarta. Google Scholar

Sugianto, V. Y. (2016). Analisis kinerja keuangan sebelum dan sesudah go public pada PT. Garuda indonesia tbk tahun 2007-2014. Jurnal Bisnis dan Manajemen, 52(11). Google Scholar

Sugiyono. (2013) Statistika Untuk Penelitian. Alfabeta. Bandung.

Susyanti, J., \& Wahono, B. (2018). Analisa Kinerja Keuangan Perusahaan Real Estate Dan Property Sebelum Dan Selama Diberlakukannya PP No. 34 Tahun 2016. Jurnal Ilmiah Riset Manajemen, 7(03). Google Scholar

World Steel Association. (2019) Steel Statistical Yearbook 2019, Concise Version. Economics Committee. Brussels, Belgium.

\section{Copyright holder:}

Mochamad Riza Inayatullah, Bambang Mulyana (2021)

First publication right:

Syntax Idea

This article is licensed under:

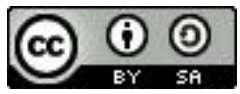

